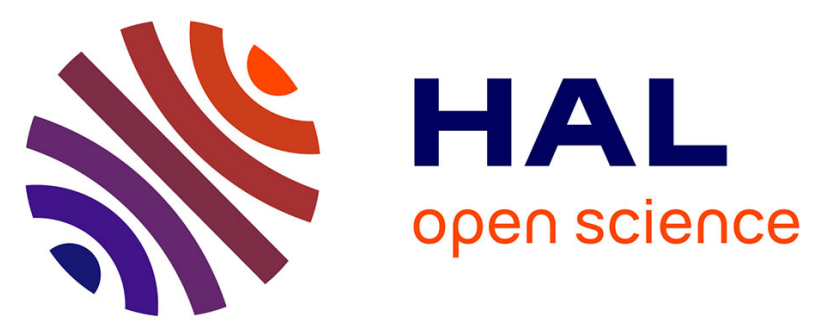

\title{
Do artificial and natural defoliation have similar effects on physiology of Eucalyptus globulus Labill. seedlings?
}

Audrey G. Quentin, Elizabeth A. Pinkard, Christopher L. Beadle, Timothy J. Wardlaw, Anthony P. O'Grady, Stephen Paterson, Caroline L. Mohammed

\section{- To cite this version:}

Audrey G. Quentin, Elizabeth A. Pinkard, Christopher L. Beadle, Timothy J. Wardlaw, Anthony P. O'Grady, et al.. Do artificial and natural defoliation have similar effects on physiology of Eucalyptus globulus Labill. seedlings?. Annals of Forest Science, 2010, 67 (2), 10.1051/forest/2009096 . hal00883566

\section{HAL Id: hal-00883566 https://hal.science/hal-00883566}

Submitted on 1 Jan 2010

HAL is a multi-disciplinary open access archive for the deposit and dissemination of scientific research documents, whether they are published or not. The documents may come from teaching and research institutions in France or abroad, or from public or private research centers.
L'archive ouverte pluridisciplinaire HAL, est destinée au dépôt et à la diffusion de documents scientifiques de niveau recherche, publiés ou non, émanant des établissements d'enseignement et de recherche français ou étrangers, des laboratoires publics ou privés. 


\title{
Do artificial and natural defoliation have similar effects on physiology of Eucalyptus globulus Labill. seedlings?
}

\author{
Audrey G. QUENTIN ${ }^{1,2 *}$, Elizabeth A. PINKARD ${ }^{1,2,3}$, Christopher L. BEAdLE ${ }^{1,2,3}$, Timothy J. WARDLAW ${ }^{4}$, \\ Anthony P. O'Grady ${ }^{1,5}$, Stephen PATERson ${ }^{1,5}$, Caroline L. Mohammed ${ }^{1,2,3}$ \\ ${ }^{1}$ Cooperative Research Centre for Forestry, Private Bag 12, Hobart, Tasmania 7001, Australia \\ ${ }^{2}$ School of Agricultural Science, University of Tasmania, Private Bag 54, Hobart, Tasmania 7001, Australia \\ ${ }^{3}$ CSIRO Sustainable Ecosystems, Private Bag 12, Hobart, Tasmania 7001, Australia \\ ${ }^{4}$ Forestry Tasmania, 79 Melville St., Hobart, Tasmania 7000, Australia \\ ${ }^{5}$ Plant Science, University of Tasmania, Private Bag 54, Hobart, Tasmania 7001, Australia
}

Keywords:

Paropsisterna agricola /

growth /

biomass allocation /

photosynthetic capacity /

carbohydrate

(Received 25 March 2009; accepted 16 July 2009)

\author{
Mots-clés : \\ Paropsisterna agricola / \\ croissance / \\ allocation de la biomasse / \\ capacité de la photosynthèse / \\ glucides
}

\begin{abstract}
- Artificial defoliation is often used to simulate defoliation by herbivory and is usually considered a good indication of a plant's response to a given type of damage. However, the findings of studies directly comparing the two defoliation types are inconsistent.

- Here, the short term effects of artificial and insect defoliation by larvae of Paropsisterna agricola on growth, biomass allocation and photosynthetic capacity of Eucalyptus globulus seedlings were compared in a glasshouse experiment. The artificial defoliation was carried out to closely resemble the spatial patterns observed for insect defoliation.

- Height and diameter increments were reduced as a result of insect defoliation, whereas artificial defoliation had no significant effect on height. Increased photosynthetic capacity was observed in response to both treatments, but the magnitude of this increase was larger in insect- than in artificially-defoliated seedlings. Significant reductions in foliar carbohydrate content and total biomass were noticeable in artificially-defoliated seedlings. Although the foliar carbohydrate levels also decreased across the crown zones following insect defoliation treatment, seedlings allocated a large amount of their biomass in the branches of the damaged zone.

- Despite our best endeavours to simulate insect defoliation in the artificial treatment, the latter may not reflect accurately the full strength of the effects. However, artificial and insect defoliation were similar in their direction of the responses they caused in E. globulus seedlings.
\end{abstract}

Résumé - Les défoliations artificielle et naturelle ont-elles des effets similaires sur la physiologie de jeune plants d'Eucalyptus globulus Labill.?

- La défoliation artificielle est couramment employée pour simuler la défoliation par les insectes herbivores et elle est généralement considérée comme un bon indicateur de la réponse des plantes pour un type de dommage donné. Cependant, les résultats d'études comparant directement les deux types de défoliation sont inconsistants.

- Ici, les effets court terme des défoliations artificielles et naturelles par la larve de Paropsisterna agricola ont été comparés au plan de la croissance, de l'allocation de la biomasse et de la capacité de photosynthèse dans une expérimentation conduite en serre. La défoliation artificielle a été menée pour ressembler étroitement aux modèles spatiaux observés avec la défoliation par les insectes.

- À la suite de la défoliation par les insectes, les accroissements en hauteur et en diamètre ont été réduits, alors que la défoliation artificielle n'a eu aucun effet significatif sur la hauteur. L'augmentation de la capacité de photosynthèse a été observée en réponses aux deux traitements, mais l'ampleur de cette augmentation a été plus forte pour les plants défoliés par les insectes que pour les plants artificiellement défoliés. Des réductions significatives de la teneur foliaire en glucides et de la biomasse totale ont été notées chez les plants artificiellement défoliés. Malgré la réduction générale de la teneur

\footnotetext{
*Corresponding author: Audrey.Quentin@crcforestry.com.au
} 
en glucides à la suite de la défoliation par les insectes, les jeunes plants assignèrent une importante partie de la biomasse aux branches de la zone endommagée.

- Malgré nos meilleures tentatives pour simuler la défoliation par les insectes dans le traitement artificiel, ce dernier ne reflète pas avec exactitude toute l'ampleur de l'impact engendré. Cependant, les défoliations artificielles et naturelles ont entraîné chez les jeunes plants d'E. globulus des réponses qui allaient dans le même sens.

\section{INTRODUCTION}

Logistic constraints on conducting experiments related to insect defoliation in the field make assessments of herbivory on plants hosts difficult. An alternative option consists of simulating herbivory through mechanical defoliation and studying plant responses. Such an approach offers significant insights into the ecological, physiological and morphological responses of plants to herbivory and also provides convenient way to test plant responses to various types and levels of defoliation (Conrad and Dhileepan, 2007; Hjältén, 2004). Additionally, artificial defoliation trials are statistically reliable as the exact magnitude and distribution of defoliation can be controlled and measured (Hjältén, 2004).

However, it is impossible to accurately replicate real herbivore damage and several problems have been identified (Baldwin, 1990; Hjältén, 2004). Artificial defoliation methods are often selected based on logistical considerations such as time taken to defoliate plants, and may bear no resemblance to the spatial and temporal patterns of insect damage (e.g. Heichel and Turner, 1983; Hoogesteger and Karlsson, 1992; Ovaska et al., 1993; Reich et al., 1993; Vanderklein and Reich, 1999). Artificial defoliation studies with Eucalyptus globulus Labill. have involved removal of entire leaves whereas this rarely occurs with its main defoliating pests (e.g. Pinkard et al., 2007; Turnbull et al., 2007). Baldwin (1990) has indicated a differential sensitivity to artificial and natural defoliation, even when the former is rigorously matched to the mechanism of natural defoliation. Therefore, the following question arises: how different are plant responses to artificial defoliation from those induced by herbivory?

Previous studies have compared the two approaches in slow-growing evergreen conifer trees including lodgepole pine [Pinus contorta Dougl. ex Loud.] (Britton, 1988), balsam-fir [Abies balsamea (L.) Mill.] (Piene and Little, 1990), ponderosa pine [Pinus ponderosa Dougl. ex Laws.] (Sanchez-Martinez and Wagner, 1994), Scots pine [Pinus sylvestris L.] (Lyytikainen-Saarenmaa, 1999) and fastgrowing evergreen conifer trees such as Douglas-Fir [Pseudotsuga menziesii (Mirb.) Franco] (Chen et al., 2002). These studies have only examined responses in terms of impacts on growth and biomass allocation, and sought not sort to address the underlying processes driving these responses. Furthermore these findings have not always been consistent, with both similar (Britton, 1988; Chen et al., 2002; Sanchez-Martinez and Wagner, 1994) and contrasting (Baldwin, 1990; LyytikainenSaarenmaa, 1999) effects reported, suggesting for the need of deeper mechanistic understanding. For instance, increase in photosynthetic rate along with changes in foliar nitrogen and carbohydrate contents commonly occur following defoliation events in a large range of tree species (e.g. Chen et al., 2001; Hoogesteger and Karlsson, 1992; Ovaska et al., 1993; Pinkard et al., 1998; Reich et al., 1993; Vanderklein and Reich, 1999).

Paropsisterna bimaculata (Olivier) (previously Chrysophtharta spp.), Paropsisterna agricola (Chapuis), Mnesampela privata (Guenée), Uraba lugens (Walker), Cadmus australis and Gonipterus scutellatus Gyllenhal are among the most important defoliators of established E. globulus plantations throughout Australia (Floyd et al., 2002; Loch, 2006; Loch and Floyd, 2001). These herbivores feed on new shoots and mostly juvenile leaves of eucalypts, which if of sufficient magnitude can lead to the characteristic damage of the upper crown called the "broom-topping effect" (Loch, 2005). The recent increased activity of $P$. agricola in southern Australia has been facilitated by rapid expansion in plantings of E. globulus and E. nitens (Dean and Maiden). Currently, P. agricola costs annually the timber industry AU $\$ 12000$ in pesticide applications, and up to AU $\$ 870$ per hectare in lost production through reductions in tree height, diameter and volume, and potential growth malformation (Nahrung, 2003).

Here we examine effects of $P$. agricola feeding on the juvenile sessile leaves and buds of $E$. globulus seedlings. It is not known whether artificial defoliation can be used to simulate the effects of $P$. agricola. This experiment compared the effects of artificial and insect defoliation by larvae of P. agricola on mean $\mathrm{CO}_{2}$ assimilation, stem growth and above-ground biomass production, and foliar chemistry in $E$. globulus seedlings. Two hypotheses were tested: firstly that seedlings respond to defoliation by changing physiological processes to compensate the loss of foliage and, secondly that there are differences between the effects of artificial and insect defoliation on photosynthesis, growth and biomass allocation of E. globulus seedlings.

\section{MATERIALS AND METHODS}

\subsection{Plant material}

Ten-cm high E. globulus seedlings raised in a commercial nursery were planted into $5 \mathrm{dm}^{3}$ pots filled with a mixture of pine bark $(70 \%)$, washed sand $(20 \%)$ and sieved loam (10\%) (Horticultural Supplies, Brighton, Tasmania). The seedlings were grown in a shadehouse for six months during which time they were watered to saturation three times daily, and fertilised twice with $15 \mathrm{~g}$ slow release nutrients (Osmocote ${ }^{\circledR}$ containing 16-3.5-10 of N-P-K) using soil surface application. After six months seedlings averaged $50-\mathrm{cm}$ height and were re-potted into $9 \mathrm{dm}^{3}$ pots on 27th December 2006. Twentyfour plants were selected on 9th February 2007 and stratified into eight block-groups of three plants based on similar height and leafarea development. Overall, the average height of the seedlings was 
$84 \mathrm{~cm}$ within a range between 61 and $103 \mathrm{~cm}$. One plant from each group was allocated randomly to three treatments. The seedlings were transferred into a glasshouse and grown at $23{ }^{\circ} \mathrm{C}, 45 \%$ relative humidity and $16 \mathrm{~h}$ photoperiod until the start of the experiment four days later.

\subsection{Insect culture}

Adults of P. agricola were collected in December 2006 from a $E u$ calyptus nitens (Dean and Maiden) plantation near the Huon River, Tasmania $\left(43.00{ }^{\circ} \mathrm{S}, 146.49{ }^{\circ} \mathrm{E}\right.$, elevation $\left.100 \mathrm{~m}\right)$. Adults were collected from the field and maintained on fresh E. globulus juvenile foliage at $20{ }^{\circ} \mathrm{C}$ and $16 \mathrm{~h}$ photoperiod. Eggs laid were transferred to young foliage and stored at $4{ }^{\circ} \mathrm{C}$ to arrest development. Once sufficient eggs had been collected, eggs were reared at $20^{\circ} \mathrm{C}$. By $10 \mathrm{~d}$, the eggs had hatched and the larvae had passed through first and second instars and were transferred to treatment seedlings to feed while they passed through their final two instars before pupation.

\subsection{Treatments and experimental design}

Each seedling was divided initially into two equal zones by height and a third zone was added subsequently. Zone 1 (Z1) was totally separated from Zone 2 (Z2) by an additional piece of netting. Z2 included the defoliated top-half of the crown of the defoliated seedlings while Zone 3 (Z3) included the newly expanded crown that developed following treatment.

The three treatments applied to the eight seedlings in each treatment were no defoliation (control), insect defoliation and artificial defoliation. For the insect defoliation, larvae of P. agricola $(\sim 100$ per seedling) were distributed by hand onto sessile leaves throughout the Z2 canopy on 13th February 2007. The larvae fed for five days, when the visually-estimated target defoliation level of $25 \%$ was achieved; all larvae were then removed by hand. This estimated decrease in leaf area by insect defoliation was confirmed using the Crown Damage Index (CDI) (Stone et al., 2003) as being 25\%. For the artificial defoliation, sessile leaves and buds in $\mathrm{Z} 2$ were snipped manually with scissors. To simulate the spatial feeding pattern of $P$. agricola, both the complete and partial removal of leaf and bud material of similar age and location was required. The most practical way to proceed was through application of this treatment on the 15th February, that mimicked the first two days of insect defoliation, and again on the 18th February, that mimicked the additional three days of insect defoliation. The estimated level of artificial defoliation was confirmed using the Crown Damage Index (CDI) (Stone et al., 2003) as being $25 \%$.

All seedlings were placed in individual cages $(99 \times 85 \times 62 \mathrm{~cm})$ on the same day fitted with nylon netting that allowed penetration of $\sim 65 \%$ incident light. On 18th February 2007, all cages were removed after the defoliation period ended. Measurements commenced on 26th February 2007 (D0), $8 \mathrm{~d}$ after the defoliation treatments and were repeated on d 5 (D5), 17 (D17), and 23 (D23).

\subsection{Stem growth}

Height $(\mathrm{cm})$ and over-bark basal stem diameter ( $\mathrm{mm} ; \sim 1 \mathrm{~cm}$ above the soil surface) of the seedlings were initially measured on 13th February 2007 and then on four occasions after the start of the experiment (D0, D17, D23 and at the time of the harvest).

\subsection{Gas exchange and chlorophyll concentration}

Light-saturated photosynthetic rate $\left(A_{\max }, \mu \mathrm{mol} \mathrm{m} \mathrm{m}^{-2} \mathrm{~s}^{-1}\right)$ and stomatal conductance $\left(g_{\mathrm{s}}\right.$, mol $\left.\mathrm{m}^{-2} \mathrm{~s}^{-1}\right)$ were measured on three undamaged and expanding leaves per seedling in $\mathrm{Z} 2$ at $360 \mu \mathrm{mol} \mathrm{mol}{ }^{-1} \mathrm{CO}_{2}$ using an open-flow infra-red portable gasanalysis system (CIRAS-1, PP Systems, Herts, UK) fitted with a light source providing a photosynthetic photon flux of $1500 \mu \mathrm{mol} \mathrm{m} \mathrm{m}^{-2} \mathrm{~s}^{-1}$. Measurements were made on four occasions (D0, D5, D17, D23) using healthy and entire leaves between 1000 and $1400 \mathrm{~h}$ Eastern Standard Time concurrent with growth measurements. Air temperature and relative humidity within the chamber were between $23-25{ }^{\circ} \mathrm{C}$ and $45-50 \%$, respectively.

A SPAD chlorophyll meter (model 502, Konica-Minolta, Hong Kong, China) was used to estimate leaf chlorophyll index (Palacio et al.) on the same three leaves used for the gas exchange measurements. Chlorophyll concentration $\left(C h l, \mathrm{mg} \mathrm{m}^{-2}\right)$ is strongly and linearly related to $C I$ (see Pinkard et al., 2006). In this study, chlorophyll index was converted to concentration using the equation, $\operatorname{Ln}[C h l]=$ $1.49 \times \operatorname{Ln}[C I]-6.49$ after confirming that this was not affected by defoliation treatments using a group linear regression analysis on Genstat10 (Quentin A.G., unpublished data).

\subsection{Foliar chemistry}

At D27, three leaves from Z2 (used for the final gas-exchange and chlorophyll meter measurements) and three leaves in the process of expanding from $\mathrm{Z} 3$ of each seedling were tagged and collected for analysis of $C h l$, nitrogen $(\mathrm{N})$, and phosphorus $(\mathrm{P})$ concentrations, soluble sugars $(S S)$ and starch $(S t)$ contents, and the ratio of fresh area: dry mass (specific leaf area, $S L A$ ). Leaves were separated into two halves bilaterally. On the first half, total $C h l$ was extracted from leaf discs $\left(0.93 \mathrm{~cm}^{2}\right)$ using the acetone method (Agency, 1994). Chlorophyll content was calculated with the equations of Arnon (1949). The remaining of the first half leaf was dried at $65^{\circ} \mathrm{C}$ for $48 \mathrm{~h}$ to constant weight and ground in a hammer mill. Samples were prepared for foliar $\mathrm{N}$ and $\mathrm{P}$ analyses using a continuous flow colorimetric autoanalyser (Mcleod, 1992). The other half of the three leaves was dried and ground similarly for colorimetric determination of total $S S$ and $S t$ content (Buysse and Merckx, 1993; Dubois et al., 1956). Concentration of St (glucose units) was calculated as described in Palacio et al. (2007). Total non-structural carbohydrate $(T N C)$ was the sum of SS and St. Foliar contents $\left(\mathrm{g} \mathrm{m}^{-2}\right)$ of $T N C$ were calculated using their concentrations and SLA.

\subsection{Biomass harvesting}

All seedlings were harvested on 25th March 2007 (D27). Plant material from the three zones was partitioned into stem, branches and leaves and oven-dried to constant mass at $65{ }^{\circ} \mathrm{C}$ (approximately $72 \mathrm{~h}$ ) and weighed. Ten fully-expanded leaves per plant were collected from each crown position for analysis of leaf area:dry mass ratio (specific leaf area; $S L A$ ) using a planimeter (Delta-T Device, Cambridge, UK). The samples were representative of the range of leaf sizes found on the seedlings. Analysis of biomass allocation and SLA were determined on each individual dry mass component and components pooled together. 
Table I. Summary of significant ANOVA results showing degrees of freedom (d.f.), $F$ and probability $(P)$ for each analysis.

\begin{tabular}{|c|c|c|c|c|}
\hline Analysis & Factor & d.f. & $F$ & $P$ \\
\hline \multirow[t]{3}{*}{$H_{\text {inc }}(\mathrm{m})$} & Trt & 2 & 5.64 & 0.011 \\
\hline & Day & 3 & 244 & 0.001 \\
\hline & Day $\times$ Trt & 6 & 3.24 & 0.030 \\
\hline \multirow[t]{3}{*}{$D_{\text {inc }}(\mathrm{mm})$} & Trt & 2 & 9.91 & 0.001 \\
\hline & Day & 3 & 119 & 0.001 \\
\hline & Day $\times$ Trt & 6 & 3.97 & 0.005 \\
\hline \multirow[t]{3}{*}{$A_{\max }\left(\mu \mathrm{molm}-2 \mathrm{~s}^{-1}\right)$} & Trt & 2 & 14.2 & 0.001 \\
\hline & Day & 3 & 3.65 & 0.023 \\
\hline & Day $\times$ Trt & 6 & 1.06 & 0.384 \\
\hline \multirow[t]{3}{*}{$g_{\mathrm{s}}\left(\mathrm{mol} \mathrm{m} \mathrm{m}^{-2} \mathrm{~s}^{-1}\right)$} & Trt & 2 & 3.98 & 0.026 \\
\hline & Day & 3 & 13 & 0.001 \\
\hline & Day $\times$ Trt & 6 & 2.31 & 0.046 \\
\hline \multirow[t]{3}{*}{$W U E_{\mathrm{i}}\left(\mu \mathrm{mol} \mathrm{mol}{ }^{-1}\right)$} & Trt & 2 & 0.18 & 0.834 \\
\hline & Day & 3 & 4.24 & 0.010 \\
\hline & Day $\times$ Trt & 6 & 3.05 & 0.011 \\
\hline \multirow[t]{3}{*}{$C h l\left(\mathrm{mg} \mathrm{m}^{-2}\right)$} & Trt & 2 & 16.2 & 0.001 \\
\hline & Day & 3 & 7.49 & 0.001 \\
\hline & Day $\times$ Trt & 6 & 5.95 & 0.001 \\
\hline \multirow[t]{3}{*}{$A / C h l\left(\mathrm{mmol} \mathrm{g}^{-1} \mathrm{~s}^{-1}\right)$} & Trt & 2 & 3.77 & 0.031 \\
\hline & Day & 3 & 3.52 & 0.026 \\
\hline & Day $\times \operatorname{Trt}$ & 6 & 0.65 & 0.655 \\
\hline
\end{tabular}

\subsection{Data analysis}

Increments of stem growth was calculated for height $\left(H_{\text {inc }}, \mathrm{cm}\right)$ and diameter $\left(D_{\text {inc }}, \mathrm{mm}\right)$ as the growth measured on day $j$ less the growth initially measured. Instantaneous water-use efficiency $\left(W U E_{i}=A_{\max } / g_{\mathrm{s}} ; \mu \mathrm{mol} \mathrm{mol}{ }^{-1}\right)$, nitrogen-use efficiency, $(N U E=$ $\left.A_{\max } / N ; \mathrm{mmol} \mathrm{mol}^{-1}\right), A_{\max }:$ chlorophyll concentration $\operatorname{ratio}(\mathrm{A} / \mathrm{Chl}$; $\mu \mathrm{mol} \mathrm{g}^{-1} \mathrm{~s}^{-1}$ ), stem mass ratio (SMR = stem mass/total mass.), branch mass ratio (BMR $=$ branch mass/total mass) and leaf mass ratio (LMR = leaf mass/total mass).

The effect of defoliation on growth and gas exchanges parameters were analysed by split plot for repeated measures. Two-way analysis of variance (ANOVA) was used to determine the effects defoliation treatments, crown zones and their interactions on biomass variables. The Genstat10 software (Genstat Committee, 1989) was used for the ANOVA and determination of error bars using the least squares method (LSD).

\section{RESULTS}

\subsection{Growth increment}

Defoliation treatments significantly affected stem growth over the period of the experiment (Tab. I). Following insect defoliation, $H_{\text {inc }}$ and $D_{\text {inc }}$ were significantly reduced compared to

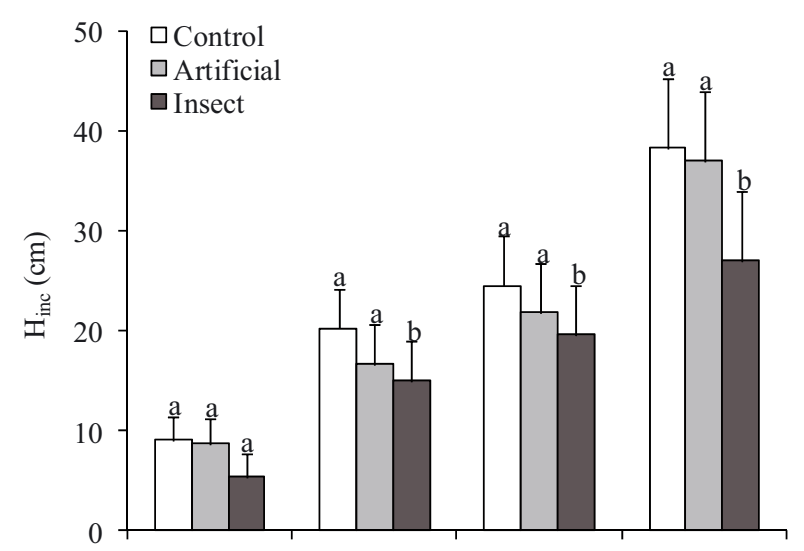

(a)

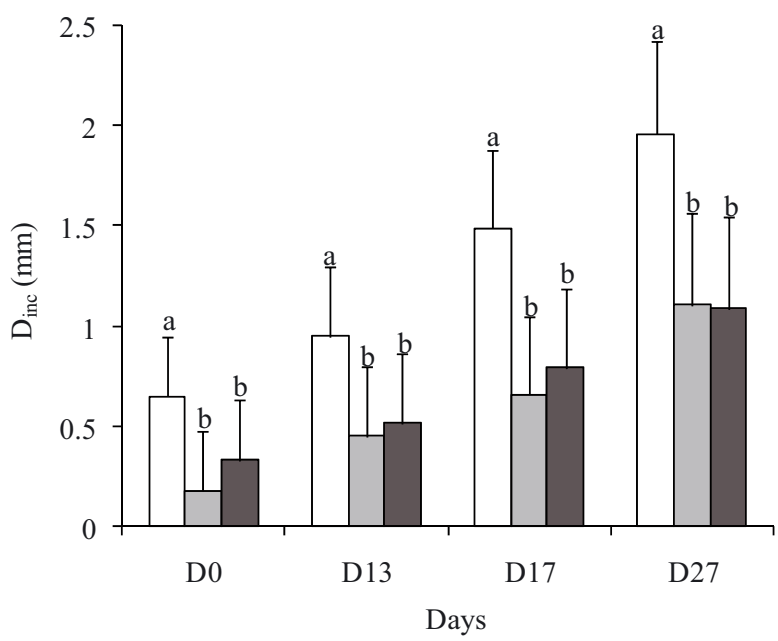

(b)

Figure 1. Mean increments of (a) height $\left(H_{\text {inc }}\right)$ and (b) basal diameter $\left(D_{\text {inc }}\right)$ measured on four occasions (D0, D17, D23 and D27) for control, artificial and insect. Error bars show least square differences $(\alpha<0.05)$. LSD homogeneous groupings are identified by letters $(\alpha<0.05)$.

the control treatment $(P<0.05$; Figs. 1a, 1b). Although artificial defoliation had no significant effect on $H_{\text {inc }}$, it significantly affected $D_{\text {inc }}(P<0.05$; Fig. 1b).

\subsection{Photosynthesis, stomatal conductance and water-use efficiency}

Both insect and artificial defoliations resulted in significant increases in $A_{\max }$ and $g_{\mathrm{s}}$ compared to the control (Tab. I). Mean $A_{\max }$ was not significantly different between the two defoliation treatments though up-regulation was generally greater following insect than artificial defoliation $(P>0.05$; Fig. 2a). Larger values of $g_{\mathrm{s}}$ were found between D17 and D23 in insect-defoliated compared to artificially defoliated and control seedlings $(P<0.05$; Fig. 2b).

In $W U E_{i}$, there was a significant effect by date and a significant datextreatment interaction (Tab. I). By D5, $W U E_{i}$ of insect defoliated trees was significantly higher than that in the control and artificial defoliation treatments $(P<0.05$; Fig. $2 \mathrm{c})$, 

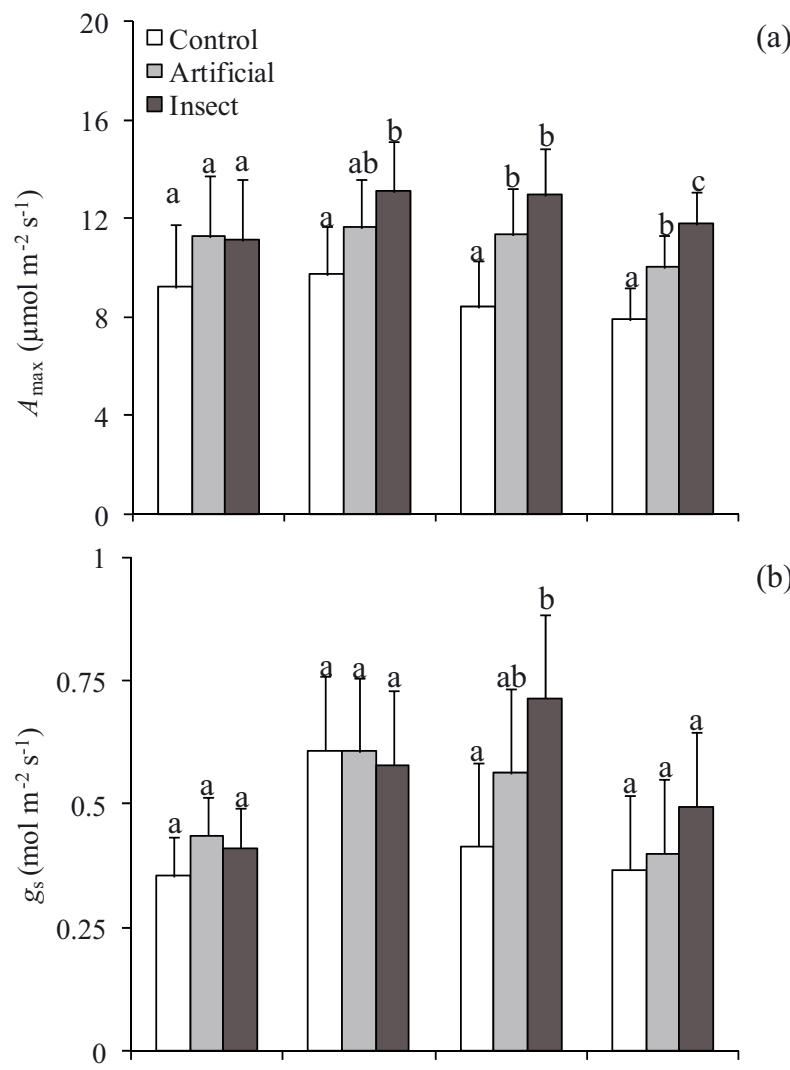

(b)

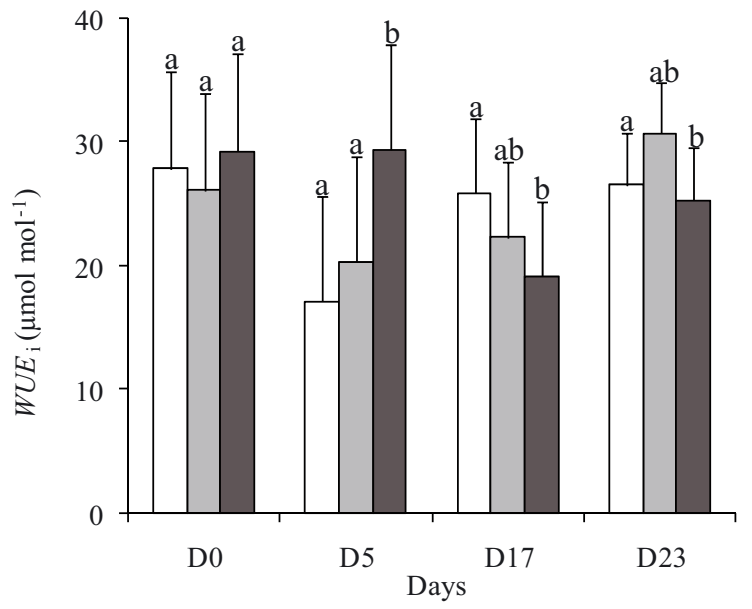

(c)

Figure 2. Mean (a) photosynthetic rate $\left(A_{\max }\right)$, (b) stomatal conductance $\left(g_{\mathrm{s}}\right)$, and (c) water-use efficiency $\left(W U E_{\mathrm{i}}\right)$ for control, artificial and insect defoliation treatments on four occasions (D0, D5, D17, D23). Error bars show least square differences $(\alpha<0.05)$. LSD homogeneous groupings are identified by letters $(\alpha<0.05)$.

as a result of a larger increase in $A_{\max }$. Instantaneous water use efficiency of the insect defoliated trees significantly declined by D17, due to increased $g_{\mathrm{s}}$. In contrast $W U E_{i}$ of the control trees increased, in response to decreased $g_{\mathrm{s}}$ by the end of the study ( $P<0.05$; Fig. 2c). The effect of artificial defoliation on $W U E_{i}$ was visible only at D23 compared to the control $(P<0.05$, Fig. 2c) .
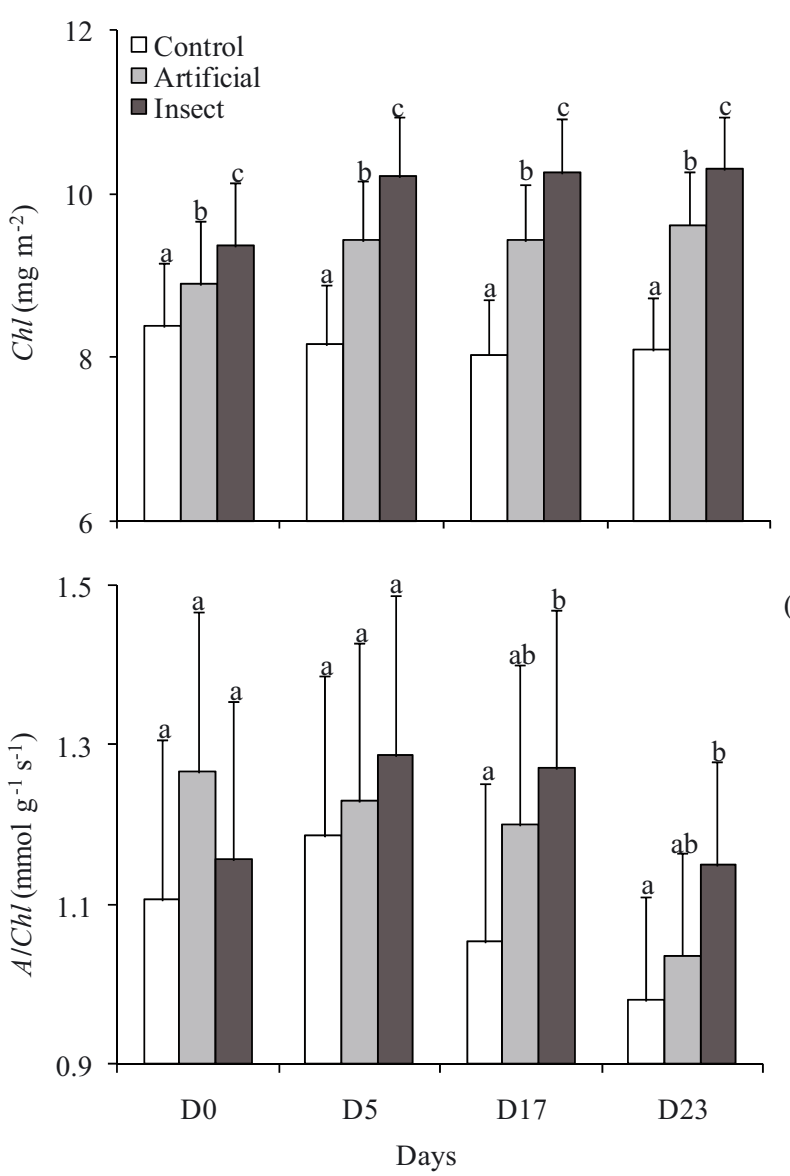

(b)

Figure 3. Mean (a) chlorophyll concentration $(C h l)$ and (b) ratio between $A_{\max }$ and $C h l(A / C h l)$ on four occasions (D0, D5, D17, D23) following defoliation treatments. Error bars show least square differences $(\alpha<0.05)$. LSD homogeneous groupings are identified by letters $(\alpha=0.05)$.

\subsection{Foliar chlorophyll concentration and $A_{\max }$}

Defoliation treatments significantly affected $C h l$ and $A / C h l$ (Tab. I). Foliar $C h l$ increased in both defoliation treatments (Fig. 3a) and the largest increases were observed following insect defoliation $(P<0.001$, Fig. 3a). In the control treatment, $C h l$ remained relatively constant throughout the experiment (Fig. 3a). A/Chl ratios were generally higher in the insect-defoliated seedlings than in the artificial and controls, however this difference was only significant for insect and control treatments except on D23 ( $P<0.05$, Fig. 3b).

\subsection{Foliar $N$ concentration and photosynthetic nitrogen-use efficiency (NUE)}

By D27, insect defoliation resulted in higher $N$ concentration $(P<0.05$; Fig. 4a) in Z2, whereas artificial treatment did not differ from the control treatment $(P>0.1$; Fig. 4a). In $\mathrm{Z} 3$, there were no differences between treatments $(P>0.1$; 

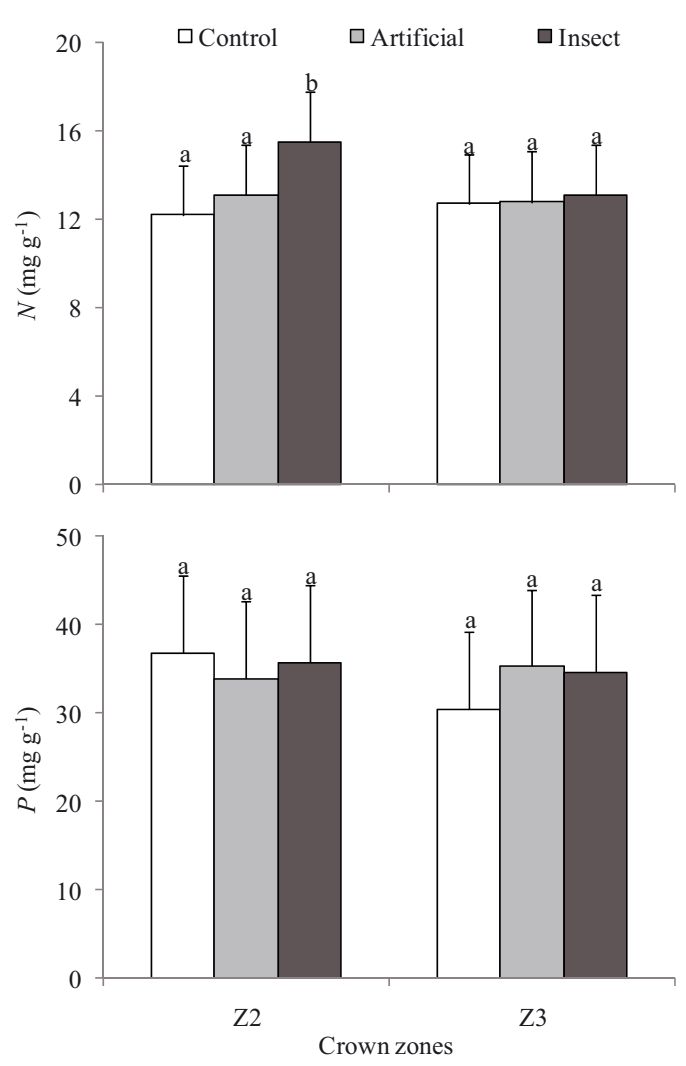

Figure 4. Means (a) nitrogen $(N)$ and (b) phosphorus $(P)$ concentrations on D27. following defoliation treatments in zones 2 and 3 (Z2, $\mathrm{Z3})$. Error bars show least square differences $(\alpha<0.05)$. LSD homogeneous groupings are identified by letters $(\alpha=0.05)$.

Fig. 4a). In Z2, NUE did not differ between treatments (data not shown). There was no significant relationship between $A_{\max }$ and $N$ (data not shown). Foliar $P$ was unaffected by both insect and artificial defoliation treatments (Fig. 4b).

\subsection{Foliar non-structural carbohydrate content}

Defoliation treatments had significant impacts on foliar $T N C$, however this response varied between zones. In Z2 there were no differences between control and artificial treatments, however insect defoliation resulted in a significant reduction in $T N C$ (both $S S$ and $S t, P<0.05$; Tab. I) compared to both control and artificial treatments. In Z3, where leaves were not directly affected by the treatment but expanded afterward, $S S$ were significantly reduced in the artificial treatment compared to control treatment. Starch and TNC were significantly lower in both artificial and insect defoliation treatments $(P<0.05$; Tab. II), compared to controls.

\subsection{Specific leaf area and biomass partitioning}

Zone had a significant effect on SLA $(P<0.001)$ with the highest increases occurring in $\mathrm{Z} 3$ and the lowest in $\mathrm{Z} 1$
Table II. Mean foliar non-structural carbohydrates contents for control and defoliated seedlings across Zones 2 and 3 (Z2, Z3) on D23 of the experiment. LSD homogeneous groupings are identified by letters $(\alpha=0.05)$. Values were taken from Genstat. TNC $=$ total nonstructural carbohydrates.

\begin{tabular}{|c|c|c|c|}
\hline & Control & Artificial & Insect \\
\hline \multicolumn{4}{|c|}{ Content in $\mathrm{Z} 2\left(\mathrm{~g} \mathrm{~m}^{-2}\right)$} \\
\hline Soluble sugars & $4.65( \pm 0.82) \mathrm{a}$ & $4.30( \pm 0.47) \mathrm{a}$ & $2.72( \pm 0.29) b$ \\
\hline Starch & $1.83( \pm 0.28) \mathrm{a}$ & $1.76( \pm 0.28) \mathrm{a}$ & $0.99( \pm 0.19) \mathrm{b}$ \\
\hline $\mathrm{TNC}$ & $6.48( \pm 0.98) a$ & $6.06( \pm 0.74) \mathrm{a}$ & $3.7( \pm 0.46) b$ \\
\hline \multicolumn{4}{|c|}{ Content in $\mathrm{Z} 3\left(\mathrm{~g} \mathrm{~m}^{-2}\right)$} \\
\hline Soluble sugars & $4.70( \pm 1.10) \mathrm{a}$ & $2.79( \pm 0.32) \mathrm{b}$ & $3.45( \pm 0.89) \mathrm{ab}$ \\
\hline Starch & $1.72( \pm 0.57) \mathrm{a}$ & $0.77( \pm 0.15) \mathrm{b}$ & $0.64( \pm 0.11) b$ \\
\hline TNC & $6.43( \pm 1.65) \mathrm{a}$ & $3.56( \pm 0.46) \mathrm{b}$ & $4.09( \pm 0.99) \mathrm{b}$ \\
\hline
\end{tabular}

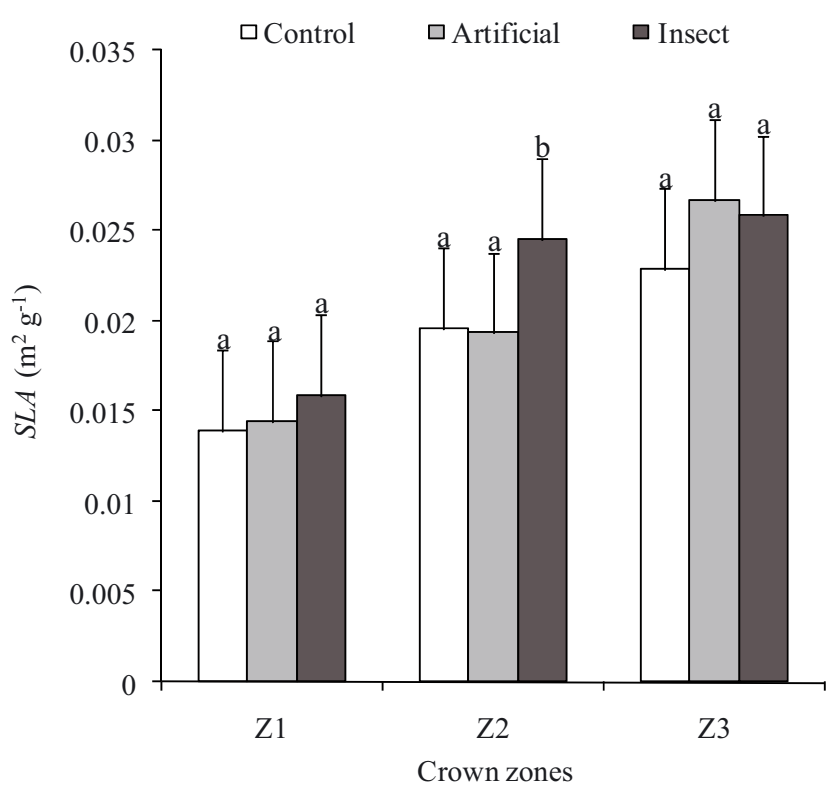

Figure 5. Mean specific leaf area (SLA) for control and defoliated seedlings on D23. Error bars show least square differences $(\alpha<0.05)$. LSD homogeneous groupings are identified by letters $(\alpha=0.05)$.

(Fig. 5). Significant increase in $S L A$ of Z2 due to insect defoliation $(25 \%)$ was observed $(P<0.05$; Fig. 5$)$. Both defoliation treatments also caused $15 \%$ increase in SLA of Z3 $(P>0.05$; Fig. 5).

Both artificial and insect defoliation significantly reduced total biomass by $28.3 \%$ and $16 \%$, respectively, compared to the control treatment $(P<0.05)$. Artificially defoliated seedlings allocated less branch biomass in $\mathrm{Z} 1$ but more in $\mathrm{Z} 2$ compared to the control seedlings $(P>0.1$; Tab. III). They also allocated more biomass to the stem in $\mathrm{Z} 3$ than the control $(P>0.1$, Tab. III), whereas the seedlings in the insect treatments allocated less than the controls $(P>0.1$, Tab. III). However, insect defoliated seedlings allocated significantly more biomass to the branch in $\mathrm{Z} 2$ than the control seedlings $(P<0.05$; Tab. III). They also produced more foliage in Z3 than the control seedlings $(P>0.1)$, whereas seedlings in 
Table III. Mean values $( \pm$ SE) of stem mass ratio (SMR), branch mass ratio (BMR), and leaf mass ratio (LMR) across each crown zone and for the three crown zones pooled together for control and defoliated seedlings on D27 of the experiment. LSD homogeneous groupings are identified by letters $(\alpha=0.05)$.

\begin{tabular}{lcccc}
\hline Crown zones & Treatments & SMR & BMR & LMR \\
\hline Zone 1 & Control & $64.7( \pm 7.8) \mathrm{a}$ & $6.9( \pm 2.7) \mathrm{a}$ & $28.4( \pm 5.2) \mathrm{a}$ \\
& Artificial & $63.6( \pm 6.1) \mathrm{a}$ & $5.6( \pm 1.9) \mathrm{a}$ & $30.8( \pm 4.9) \mathrm{a}$ \\
& Insect & $57.5( \pm 5.3) \mathrm{a}$ & $8.3( \pm 2.2) \mathrm{a}$ & $34.2( \pm 3.6) \mathrm{a}$ \\
Zone 2 & & & \\
& Control & $30.5( \pm 4.6) \mathrm{a}$ & $13.9( \pm 1.2) \mathrm{a}$ & $55.6( \pm 3.6) \mathrm{a}$ \\
& Artificial & $28.5( \pm 3.3) \mathrm{a}$ & $16.1( \pm 1.5) \mathrm{ab}$ & $55.4( \pm 2.7) \mathrm{a}$ \\
Zone 3 & Insect & $27.6( \pm 2.2) \mathrm{a}$ & $19.1( \pm 1.1) \mathrm{b}$ & $53.3( \pm 2.6) \mathrm{a}$ \\
& & & \\
& Control & $14.3( \pm 0.9) \mathrm{a}$ & $18.2( \pm 0.5) \mathrm{a}$ & $67.5( \pm 0.9) \mathrm{a}$ \\
Whole tree & Artificial & $15.6( \pm 0.7) \mathrm{a}$ & $18.4( \pm 1.5) \mathrm{a}$ & $66.0( \pm 1.8) \mathrm{a}$ \\
& Insect & $12.0( \pm 1.0) \mathrm{a}$ & $18.9( \pm 1.4) \mathrm{a}$ & $69.1( \pm 1.0) \mathrm{a}$ \\
& & & & \\
& Control & $36.5( \pm 5.2) \mathrm{a}$ & $13.0( \pm 1.4) \mathrm{a}$ & $50.5( \pm 4.0) \mathrm{a}$ \\
& Artificial & $35.9( \pm 4.8) \mathrm{a}$ & $13.4( \pm 1.5) \mathrm{a}$ & $50.7( \pm 3.6) \mathrm{a}$ \\
& Insect & $32.4( \pm 4.4) \mathrm{a}$ & $15.4( \pm 1.4) \mathrm{a}$ & $52.2( \pm 3.3) \mathrm{a}$ \\
\hline
\end{tabular}

the artificial treatment produced relatively less foliage than the controls (Tab. III).

\section{DISCUSSION}

In various studies that measured growth rate, the type of defoliation had contrasting effects on height growth component. For example, Chen et al. (2002) reported that artificial defoliation of Douglas-Fir had a significant negative effect on height and diameter growth, whereas defoliation by western spruce budworm (Choristoneura occidentalis Freeman) had a significant negative effect only on diameter growth. In contrast, other studies with sawflies (Neodiprion sertifer (Geoff.) and N. Gillettei (Rohwer)) found significant reductions in height and diameter growth increment following both insect and artificial defoliation treatments (Britton, 1988; Sanchez-Martinez and Wagner, 1994). In E. globulus, insect defoliation had a significant adverse impact on both height and diameter growth, whereas artificial defoliation only affected the diameter growth. These results suggest that artificial defoliation underestimated the impacts of insect defoliation on height growth. The differences in the results with the previous studies may have been in the methods used to simulate the natural defoliation. However, it is generally difficult to tease out the method used for the artificial treatment and to know how well it mimics the insect activity. In Chen et al. (2002), the difference in the growth response between the two types of defoliation imposed to describe the treatments and special attention was drawn towards the removal of buds. They found that artificial defoliation removed buds completely preventing leader growth, whereas some buds were partially consumed by budworm larvae allowing shoot elongation.

Our finding suggests that the growth of E. globulus seedlings can be affected by a low level, single event of insect herbivory. Damage to buds following herbivory affects growth and patterns of resource allocation within trees (Haukioja et al., 1990). Buds determine patterns of growth that are ex- erted through the suppressive effects of dominant apical meristems upon other tissues, and because they represent "sinks" of the previous photosynthetic products (Honkanen et al., 1994), as well as being the source of both foliage and reproductive structures. Despite our best endeavours to simulate the spatial pattern of insect defoliation in the artificial treatment, the latter may have caused greater bud damage and hence had stronger effect on apical dominance and height growth. Thus the result obtained in such experiments may be as much a consequence of the relativities of bud removal as of leaf area removal.

Up-regulation of photosynthetic rates in the remaining leaves following natural and artificial defoliation has been observed in many tree species (Chen et al., 2001; Reich et al., 1993; Vanderklein and Reich, 1999) including in eucalypt species (Pinkard, 2003; Pinkard et al., 1998; Turnbull et al., 2007). Up-regulation is likely to play an important role in minimising the impact of defoliation on growth (e.g. Chen et al., 2001; Heichel and Turner, 1983; Ovaska et al., 1993; Reich et al., 1993; Vanderklein and Reich, 1999). For example, Pinkard and Beadle (1998) reported that removal of 50\% of leaf area of $E$. nitens seedlings had no impact on height growth 8 weeks later, which they related to enhanced photosynthetic rates (Pinkard et al., 1998) and changes in patterns of carbon allocation to favour leaf area development (Pinkard and Beadle, 1998). However there have no studies that we are aware of that have compared physiological responses in artificially and naturally defoliated trees. Our results indicated that for a similar pattern of damage, the photosynthetic upregulation in response to insect defoliation was $15 \%$ larger compared to artificially-defoliated seedlings, although this response varied over time (Fig. 2).

Artificial defoliation of young E. globulus in plantations substantially increased chlorophyll concentration of the remaining leaves (Pinkard et al., 2007). A similar observation was made in this study with seedlings, though insect defoliation had a stronger effect (Fig. 3a). Changes in $A_{\max }$ following partial defoliation could have been attributed to an increase in chlorophyll concentration in the remaining leaves because an 
increase in chlorophyll concentration leads to an increase in the amount of photosynthetic enzymes (Trumble et al., 1993). Although partial defoliation may result in higher foliar $N$ concentration and photosynthetic activity (Trumble et al., 1993), there was no evidence in this study of photosynthetic enhancement related to foliar $N$. Numerous studies have similarly concluded that changes in $N$ following defoliation were not responsible for enhanced photosynthesis (Ovaska et al., 1993; Reich et al., 1993; Turnbull et al., 2007), although others report a positive correlation (Hoogesteger and Karlsson, 1992).

The photosynthetic response was rapid, a finding that substantiates the view that small plants generally respond more quickly to defoliation than larger plants (Heichel and Turner, 1983), and that the response is shorter (Reich et al., 1993). Seedlings have a smaller capacity for storage of assimilates than larger plants. Thus, following loss of photosynthetic area, the demand on stored carbon reserves is likely to be intense (Cesaroli et al., 2004) and result in relatively high consumption or export of assimilates. The present study suggests that insect defoliation increased export of sugars from the leaf (Tab. II). Additionally, insect defoliation resulted in higher branch biomass than artificial defoliation in $\mathrm{Z} 2(P>0.05$; Tab. II). Based on the source-sink hypothesis (Honkanen et al., 1999), damage by herbivory modifies the strength of either pre-existing sink or newly formed sinks. In the present study, insect defoliation altered the ability of new shoots to draw resources to maintain stem growth, although it increased sink strength of directly damaged leaves. However, the suppression of apical dominance by the insect defoliation induced significant increases in allocation of biomass to the branches in the damaged crown zones (Z2). In artificially-defoliated seedlings, sufficient carbon export to the shoot tip allowed to maintain similar rates of shoot elongation and partially stimulate branching in $\mathrm{Z} 2$. This is an interesting finding and further studies would be necessary to explain how the changes in apical dominance and branching pattern have a role in growth compensatory response by E. globulus seedlings in response to insect defoliation.

Investigators have difficulty matching the response of host plants to herbivory with artificial defoliation treatments, even when the amount of tissue loss is tightly controlled. It is also suggested that the host responses at the feeding site is more related to a phytotoxic response to herbivory than salivary enzymes injected by insects (Mithöfer et al., 2005). Components of insect saliva, such as oxidase and sucrase, also affect host response (Steinbauer et al., 1997). For example, Amorbus obscuricornis (Westwood) (Heteroptera: Coreidae) caused wilting and necrosis of apical shoots of eucalypt seedlings which led to a loss of apical dominance and height growth as well as stimulation of lateral bud development (Steinbauer et al., 1997). In this study, the browsed leaves and shoots may have been biochemically more reactive to particular salivary components of $P$. agricola than to cutting with scissors, a factor that may have contributed to reduced apical dominance and the significant reduction in height growth observed following insect defoliation.

Our results proved clearly our first hypothesis that the seedlings responded to both defoliation treatments with mea- sures showing significant differences from control. Also, there was strong evidence that support our second hypothesis that the direction of response to artificial and insect defoliation was very similar. However, the influence of differential magnitude of the responses is more difficult to ascertain. We conclude that artificial defoliation may not accurately reflect the full strength of effects from insect defoliation, and caution must be exercised in extrapolating results of simulated herbivory experiments beyond the level of the individual effects to more complex ecological interactions (Hjältén, 2004). Nevertheless, artificial defoliation still has its place in the toolbox of the ecologists. Like previous studies, our findings suggest that simulated herbivory provides a useful a priori basis for acquiring fundamental insights on the effects of insect defoliation (e.g. Eucalyptus regnans F. Muell, Candy et al., 1992). Simulating herbivory may facilitate the modelling of growth responses (Watt et al., 2007) and help the development of sophisticated tools for biological control (Conrad and Dhileepan, 2007). The appropriateness of using simulated herbivory largely depends on the question addressed and hypothesis tested (Hjältén, 2004). For future research, it would be valuable to look at how the pattern of response of a plant to pest attack is influenced by the kind of damage inflicted (defoliating insect, sap sucking insect, fungi, artificial) and the speed at which leaves are removed (instantaneous versus longterm defoliation).

Acknowledgements: Thanks to Dr Alieta Eyles and three anonymous reviewers for their valuable comments and suggestions on the earlier manuscript. We thank John Ireson and Richard Hollow from Department of Primary Industry in Newtown for using the glasshouse facilities, and Vin Patel, Dr Martin Steinbauer and Dr Mamoru Matsuki for their helpful information on the insects pests in eucalypt plantations. We are grateful to Ross Corkrey for advice on statistical analysis. Funding was provided by CRC for Forestry. O'Grady was supported by an ARC linkage grant (LP0454287).

\section{REFERENCES}

Agency U.S.E.P., 1994. Chlorophyll Determination, p. 4.

Arnon D.I., 1949. Copper enzymes in isolated chloroplasts polyphenoloxidase in Beta vulgaris. Plant Physiol. 24: 1-15.

Baldwin I.T., 1990. Herbivory simulation in ecological research. Trees 5: 91-93.

Britton R.J., 1988. Physiological effects of natural and artificial defoliation on growth of young crops of lodgepole pine. Forestry 61: 165175.

Buysse J. and Merckx R., 1993. An improved colorimetric method to quantify sugar content of plant tissue. J. Exp. Bot. 44: 1627-1629.

Candy S.G., Elliott H.J., Bashford R., and Greener A., 1992. Modelling the impact of defoliation by the leaf beetle, Chrysoptharta bimaculata (Coleoptera: Chrysomelidae), on height of Eucalytpus regnans. For. Ecol. Manage. 54: 69-87.

Cesaroli S., Scartazza A., Brugnoli E., Chaves M.M., and Pereira J.S., 2004. Effects of partial defoliation on carbon and nitrogen partitioning and photosynthetic carbon uptake by two-year-old cork oak (Quercus suber) saplings. Tree Physiol. 24: 83-90.

Chen Z., Kolb T.E., and Clancy K.M., 2001. Mechanisms of Douglas-fir resistance to western spruce budworm defoliation: bud burst phenology, photosynthetic compensation and growth rate. Tree Physiol. 21: 1159-1169. 
Chen Z., Kolb T.E., and Clancy K.M., 2002. Effects of artificial and western spruce budworm (Lepidoptera: Tortricidae) defoliation on growth and biomass allocation of Douglas-fir seedlings. J. Econ. Entomol. 95: 587-594.

Conrad K.A. and Dhileepan K., 2007. Pre-release evaluation of the efficacy of the leaf-sucking bug Carvalhotingis visenda (Heteroptera: Tingidae) as a biological control agent for cat's claw creeper Macfadyena unguis-cati (Bignoniaceae). Biocontrol Sci. Tech. 17 (303-311).

Dubois M., Gilles G.A., Hamilton J.K., Rebers P.A., and Smith F., 1956. Colorimetric method for determination of sugars and related substances. Anal. Chem. 28: 350-356.

Floyd R.B., Farrow R.A., and Matsuki M., 2002. Variation in insect damage and growth in Eucalyptus globulus. Agric. For. Entomol. 4: 109115 .

GENSTAT Committee, 1989. Genstat 5 reference manual. Clarendon Press, Oxford, UK.

Haukioja E., Ruohomiki K., Senn J., Suomela J., and Walls M., 1990. Consequences of herbivory in the mountain birch (Betula pubescens ssp torCuosa): importance of the functional organization of the tree. Oecologia 82: 238-247.

Heichel G.H. and Turner N.C., 1983. $\mathrm{CO}_{2}$ assimilation of primary and regrowth foliage of red maple (Acer rubrum L.) and red oak (Quercus rubra L.): response to defoliation. Oecologia 57: 14-19.

Hjältén J., 2004. Simulating herbivory: problems and possibilities. In: Weisser W.W. and Siemann E. (Eds.), Insects and ecosystem function, Springer-Verlag, Berlin, Germany, pp. 243-256.

Honkanen T., Haukioja E., and Kitunen V., 1999. Responses of Pinus sylvestris branches to simulated herbivory are modified by tree sink/source dynamics and by external resources. Funct. Ecol. 13: $126-140$.

Honkanen T., Haukioja E., and Suomela J., 1994. Effects of simulated defoliation and debudding on needle and shoot growth in Scots pine (Pinus sylvestris): Implications of pant source/sink relationships for plant-herbivore studies. Funct. Ecol. 8: 631-639.

Hoogesteger J. and Karlsson P.S., 1992. Effects of defoliation on radial stem growth and photosynthesis in the mountain birch (Betula pubescens ssp. tortuosa). Funct. Ecol. 6: 317-323.

Loch A.D., 2005. Mortality and recovery of eucalypt beetle pest and beneficial arthropod populations after commercial application of the insecticide alpha-cypermethrin. For. Ecol. Manage. 217: 255-265.

Loch A.D., 2006. Phenology of Eucalyptus weevil, Gonipterus scutellatus Gyllenhal (Coleoptera: Curculionidae), and chrysomelid beetles in Eucalyptus globulus plantations in south-western Australia. Agric. For. Entomol. 8: 155-165.

Loch A.D. and Floyd R.B., 2001. Insect pests of Tasmanian blue gum, Eucalyptus globulus, in south-western Australia: History, current perspectives and future prospects. Aust. Ecol. 26: 458-466.

Lyytikainen-Saarenmaa P., 1999. The responses of Scots pine, Pinus sylvestris, to natural and artificial defoliation stress. Ecol. Appl. 9: 469-474.

McLeod S., 1992. Determination of total soil and plant nitrogen using a microdistillation unit in a continous flow analyser. Anal. Chim. Acta 266: 113-117.

Mithöfer A., Wanner G. and Boland W., 2005. Effects of feeding Spodoptera littoralis on lima bean leaves. II. Continuous mechanical wounding resembling insect feeding is sufficient to elicit herbivoryrelated volatile emission. Plant Physiol. 137: 1160-1168.

Nahrung H.F., 2003. Reproductive ecology of Chrysophtharta agricola (Chapuis) (Coleoptera: Chrysomelidae). Ph.D. thesis, School of Agricultural Science, University of Tasmania.
Ovaska J., Walls M., and Vapaavuori E., 1993. Combined effects of partial defoliation and nutrient availability in cloned Betula pendula saplings. 2. Changes in net photosynthesis and related biochemical properties. J. Exp. Bot. 44: 1395-1402.

Palacio S., Maestro M., and Montserrat-Marti G., 2007. Seasonal dynamics of non-structural carbohydrates in two species of Mediterranean sub-shrubs with different leaf phenology. Environ. Exp. Bot. 59: 34-42.

Piene H. and Little C.H.A., 1990. Spruce budworm defoliation and growth loss in young balsam fir: artificial defoliation of potted trees. Can. J. For. Res. 20: 902-909.

Pinkard E.A., 2003. Physiological and growth responses related to pattern and severity of green pruning in young Eucalyptus globulus. For. Ecol. Manage. 182: 231-245.

Pinkard E.A., Battaglia M. and Mohammed C.L., 2007. Defoliation and nitrogen effects on photosynthesis and growth of Eucalyptus globulus. Tree Physiol. 27: 1053-1063.

Pinkard E.A. and Beadle C.L., 1998. Aboveground biomass partitioning and crown architecture of Eucalyptus nitens following green pruning. Can. J. For. Res. 28: 1419-1428.

Pinkard E.A. and Beadle C.L., 1998. Effects of green pruning on growth and stem shape of Eucalyptus nitens (Deane and Maiden) Maiden. New For. 15: 107-126.

Pinkard E.A., Beadle C.L., Davidson N.J. and Battaglia M., 1998. Photosynthetic responses of Eucalyptus nitens (Deane and Maiden) Maiden to green pruning. Trees 12: 119-129.

Pinkard E.A., Patel V., and Mohammed C.L., 2006. Chlorophyll and nitrogen determination for plantation-grown Eucalyptus nitens and $E$. globulus using a non-destructive meter. For. Ecol. Manage. 223: 211217.

Reich P.B., Waiters M.B., Krause S.C., Vanderklein D.W., Raffa K.F., and Tabone T., 1993. Growth, nutrition and gas exchange of Pinus resinosa following artificial defoliation. Trees 7: 67-77.

Sanchez-Martinez G. and Wagner M.R., 1994. Sawfly (Hymenoptera: Diprionidae) and artificial defoliation affects above- and belowground growth of ponderosa pine seedlings. J. Econ. Entomol. 87: 1038-1045.

Steinbauer M.J., Taylor G.S., and Madden J.L., 1997. Comparison of damage to Eucalyptus caused by Amorbus obscuricornis and Gelonus tasmanicus. Entomol. Exp. Appl. 82: 175-180.

Stone C., Matsuki M., and Carnegie A., 2003. Pest and disease assesment in young eucalypt plantations: field manual for using the Crown Damage Index, National Forest inventory, Bureau of Rural Sciences, Canberra, $30 \mathrm{p}$.

Trumble J.T., Kolodny-Hirsch D.M., and Ting I.P., 1993. Plant compensation for arthropod herbivory. Annu. Rev. Entomol. 38: 93-119.

Turnbull T.L., Adams M.A., and Warren C.R., 2007. Increased photosynthesis following partial defoliation of field-grown Eucalyptus globulus seedlings is not caused by increased leaf nitrogen. Tree Physiol. 27: 1481-1492.

Vanderklein D.W. and Reich P.B., 1999. The effect of defoliation intensity and history on photosynthesis, growth and carbon reserves of two conifers with contrasting leaf lifespans and growth habits. New Phytol. 144: 121-132.

Watt M.S., Whitehead D., Kriticos D.J., Gous S.F., and Richardson B., 2007. Using a process-based model to analyse compensatory growth in response to defoliation: Simulating herbivory by a biological control agent. Biol. Control 43: 119-129. 